\title{
Meningeal Leukaemia
}

\author{
R. M. HARDISTY and PATRICIA M. NORMAN \\ From the Department of Haematology, Institute of Child Health, The Hospital for Sick Children, \\ Great Ormond Street, London W.C.1
}

With the steady improvement in survival of children with acute leukaemia, extramedullary manifestations of the disease are being observed increasingly commonly, often while the bonemarrow itself shows no evidence of leukaemia (Nies, Bodey, Thomas, Brecher, and Freireich, 1965a; Mathé, Schwarzenberg, Mery, Cattan, Schneider, Amiel, Schlumberger, Poisson, and Wajcner, 1966). Of these extramedullary manifestations, meningeal infiltration is the one which most frequently gives rise to symptoms, and therefore merits treatment in its own right. In this paper, we present the clinical and laboratory findings in 50 episodes of meningeal leukaemia occurring in 29 children, and discuss the relation of this complication to the course of the disease as a whole.

\section{Subjects}

During the period from January 1, 1958 to February $28,1966,131$ cases of acute leukaemia have been diagnosed at The Hospital for Sick Children. In 114 of these cases the disease has been classified as acute lymphoblastic leukaemia, and of these patients, 29 (16 of whom are still alive) have so far developed meningeal involvement; this complication has not been seen in any of the 17 cases of myeloblastic or myelomonocytic leukaemia. The group with meningeal leukaemia comprises 15 girls and 14 boys, two of the boys being still alive at the time of writing. These 29 patients have suffered 50 separate episodes of meningeal involvement between them, as shown in Table I, from which it can be seen that more than $50 \%$ of those patients in whom this complication developed suffered at least one further recurrence. The haematological state of the patient's disease at the time of diagnosis of each episode is shown in Table II; about half were in haematological remission. All patients were being treated with an antimetabolite at the time of diagnosis of meningeal involvement, and 9 were also receiving adrenocortical steroids. There was no particular tendency for the complication to develop during the administration of any one antimetabolite: 18 episodes occurred in patients receiving 6-mercaptopurine, 17 during methotrexate therapy, 8 while the patient was on cyclophosphamide, and 7 while on vincristine.

\section{Clinical Features}

The frequency of presenting symptoms and signs in all 50 episodes is shown in Table III. Much the commonest were those of raised intracranial pressure, while the classical features of 'meningism' were hardly ever seen. The next most common presenting feature-often, though by no means invariably, associated with those of raised intracranial pressure-was sudden rapid weight gain, associated with a voracious appetite: the 'hypothalamic syndrome'. The weight chart of a boy in

TABLE I

Clinical Material

\begin{tabular}{|c|c|c|c|c|c|c|}
\hline & & \multicolumn{4}{|c|}{ Episodes per Patient } & \multirow{2}{*}{ Tota } \\
\hline & & 1 & 2 & 3 & 4 & \\
\hline $\begin{array}{l}\text { Patients } \\
\text { Episodes }\end{array}$ & 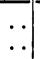 & $\begin{array}{l}14 \\
14\end{array}$ & $\begin{array}{l}11 \\
22\end{array}$ & $\begin{array}{l}2 \\
6\end{array}$ & $\begin{array}{l}2 \\
8\end{array}$ & $\begin{array}{l}29 \\
50\end{array}$ \\
\hline
\end{tabular}

TABLE II

Haematological State at Time of Diagnosis of Each of 50 Episodes of Meningeal Involvement

\begin{tabular}{|c|c|c|c|c|}
\hline \multicolumn{3}{|c|}{ Haematological State } & $\begin{array}{l}\text { Number of } \\
\text { Episodes }\end{array}$ & $\begin{array}{c}\text { Percentage of } \\
\text { Episodes }\end{array}$ \\
\hline $\begin{array}{l}\text { Remission } \\
\text { Bone-marrow } \\
\text { Peripheral blood }\end{array}$ & $\ddot{x}$ & $\ddot{*}$ & $\begin{array}{r}17 \\
7\end{array}$ & $\begin{array}{l}34 \\
14\end{array}$ \\
\hline Relapse & . & $\cdots$ & 26 & 52 \\
\hline
\end{tabular}

TABLE III

Presenting Symptoms and Signs (50 Episodes)

\begin{tabular}{|c|c|c|c|c|c|}
\hline & & & & & $\begin{array}{l}\text { Percentage of } \\
\text { Episodes }\end{array}$ \\
\hline 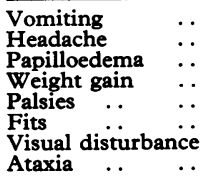 & $\begin{array}{l}\cdots \\
\cdots \\
\cdots \\
\cdots \\
\cdots \\
\cdots\end{array}$ & $\begin{array}{l}\cdots \\
\cdots \\
\cdots \\
\cdots \\
\cdots \\
\cdots\end{array}$ & $\begin{array}{l}\cdots \\
\cdots \\
\cdots \\
\cdots \\
\cdots \\
\cdots\end{array}$ & $\begin{array}{l}\cdots \\
\cdots \\
\cdots \\
\cdots \\
\cdots \\
\cdots\end{array}$ & $\begin{array}{r}80 \\
70 \\
70 \\
26 \\
16 \\
8 \\
4 \\
4\end{array}$ \\
\hline
\end{tabular}




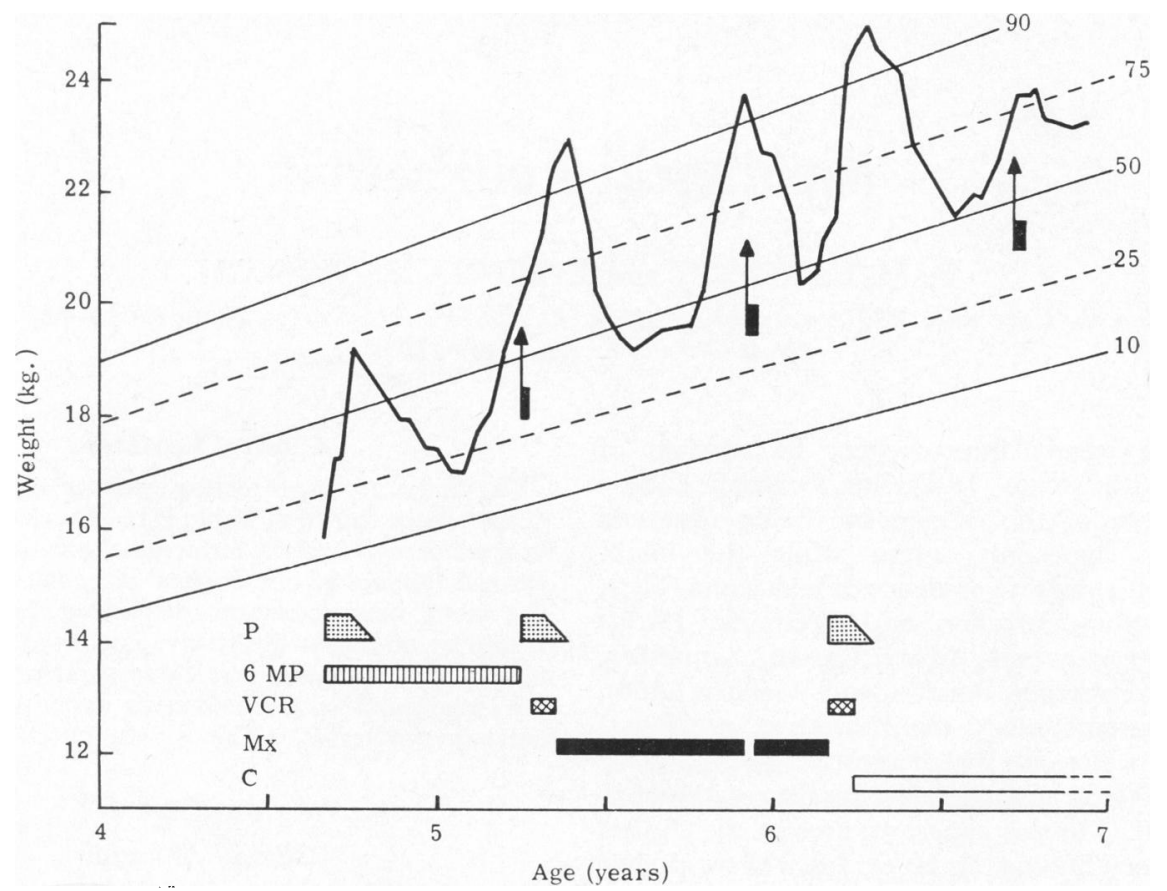

FIG. 1.-Weight chart of a boy who had 3 episodes of meningeal leukaemia. The arrows indicate the times of diagnosis (CSF examinations), and the adjacent blocks the duration of treatment with intrathecal methotrexate. $P$, prednisone; $6 M P, 6$-mercaptopurine; VCR, vincristine; $M x$, methotrexate; $C$, cyclophosphamide.

whom this was a particularly striking feature is shown in Fig. 1. The first and fourth peaks in this chart represent weight gain due to prednisone therapy, the second to meningeal involvement succeeded by prednisone therapy for the accompanying haematological relapse, and the third and fifth peaks to meningeal involvement alone. Early detection of this complication depends on regular charting of the patient's weight as well as examination of the optic fundi. As shown in Fig. 1, treatment of the meningeal leukaemia results in reversion of the weight to normal.

\section{Laboratory Findings}

In 48 out of the 50 instances the diagnosis of meningeal leukaemia was confirmed by examination of the CSF. The total cell count (Table IV) was raised in every case, the highest count being 7500 per c.mm. In most

TABLE IV

Initial CSF Cell Counts

\begin{tabular}{c|c|c|c|c|c}
\hline $\begin{array}{c}\text { Nucleated } \\
\text { Cells } \\
\text { per c.mm. }\end{array}$ & $0-20$ & $21-100$ & $101-1000$ & $>1000$ & $\begin{array}{c}\text { Not } \\
\text { Counted }\end{array}$ \\
\hline Episodes & 2 & 10 & 14 & 22 & 2 \\
\hline
\end{tabular}

instances, the cells were recognizable on stained smears as leukaemic blast cells, and mitotic figures were not infrequently seen (Fig. 2). The pressure and protein content of the fluid were each raised in about two-thirds of the cases in which they were measured.

Prognostic significance of the CSF cell count. There was no correlation between the initial CSF cell count and the immediate response to treatment. As shown in Table V, however, a count of over 1000 cells per c.mm. was associated with an appreciably higher incidence of early recurrence of meningeal involvement than that found after episodes in which the cell count was below this figure.

\section{Treatment}

Of the 50 episodes, 42 were treated by intrathecal methotrexate, and 4 by radiotherapy; 2 received adrenocortical steroids alone, and 2 were untreated. Steroids were given during 25 episodes altogether: 19 of those associated with haematological relapse, and 6 occurring during remission. Methotrexate was administered by lumbar puncture in 39 episodes, intraventricularly in 1, and by both these routes in 2 others. The dose varied between 5 and $10 \mathrm{mg}$., according to the weight of the child, and this was administered every 2 or 3 days, usually until the CSF cell count fell below 10 per c.mm. 


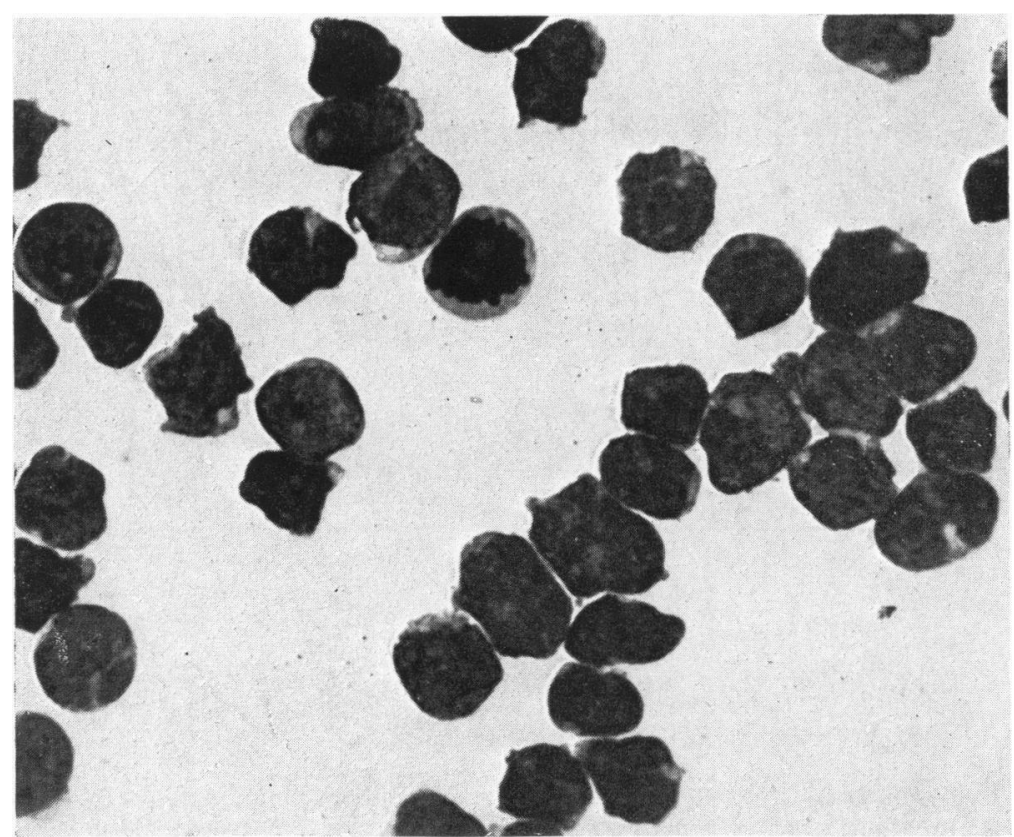

FIG. 2.-Stained film of CSF deposit, showing leukaemic blast cells, including one in mitosis. $(\times 750$.

An additional dose was usually given at the time of the last lumbar puncture, so that the final cell count may often have been lower than the last recorded. In twothirds of the cases 3 to 6 doses were sufficient, but sometimes as many as 8 or 9 were required; in these latter cases, the interval between the last 2 or 3 doses was extended up to 7 days. The total dose given for each episode is shown in Fig. 3, in absolute amount and in relation to body weight. If the patient was receiving systemic methotrexate at the time this was temporarily withheld, but other antimetabolites were continued. Intramuscular folinic acid was given in a few instances, to counter systemic methotrexate toxicity. On this régime symptoms were relieved in every case and only rarely was treatment abandoned before the cell count had fallen below 10 per c.mm.

No attempt was made in this series of patients to prevent the development or recurrence of meningeal leukaemia by giving intrathecal methotrexate before signs of this complication developed.

\section{Relation of Meningeal Involvement to the Course of the Leukaemic Process}

In Fig. 4 the time between the original diagnosis of leukaemia and that of each incident of meningeal involvement is plotted for each patient, in order of the time of occurrence of the first episode. It can be seen that meningeal leukaemia occurred with fairly constant frequency throughout the first 18 months after the original diagnosis, in 2 instances within the first 8 weeks. The time between first and second episodes varied between 4 and 48 weeks, the mean being 21 and the median 17 weeks. Third episodes occurred between 8 and 40 weeks after the second (mean 20 weeks) and the 2 fourth episodes 10 and 20 weeks, respectively, after the preceding one.

As would be expected of a complication which is likely to occur at any stage of the disease, the incidence of meningeal leukaemia increases as the patient's over-all survival is prolonged. This is shown in Table VI, in

TABLE V

Prognostic Significance of Total Nucleated Cell Count in CSF

\begin{tabular}{|c|c|c|c|c|c|c|}
\hline \multirow{2}{*}{$\begin{array}{l}\text { Initial CSF } \\
\text { Cell Count } \\
\text { (per c.mm.) }\end{array}$} & \multirow{2}{*}{$\begin{array}{c}\text { Total } \\
\text { Episodes }\end{array}$} & \multicolumn{2}{|c|}{ Meningeal Recurrences } & \multirow{2}{*}{$\begin{array}{c}\text { Died Within } \\
13 \text { Weeks }\end{array}$} & \multirow{2}{*}{$\begin{array}{c}\text { Survival for } 13 \\
\text { Weeks Without } \\
\text { Recurrence }\end{array}$} & \multirow{2}{*}{$\begin{array}{l}\text { No. of Weeks to } \\
\text { Next Recurrence } \\
\text { (mean } \pm \text { S.E.) }\end{array}$} \\
\hline & & Total & Within 13 Weeks & & & \\
\hline $\begin{array}{c}0-100 \\
101-1000 \\
>1000\end{array}$ & $\begin{array}{l}12 \\
14 \\
21\end{array}$ & $\begin{array}{l}4(33 \%) \\
8(57 \%) \\
9(43 \%)\end{array}$ & $\begin{array}{l}0 \\
2(14 \%) \\
7(33 \%)\end{array}$ & $\begin{array}{l}5(42 \%) \\
4(29 \%) \\
8(38 \%)\end{array}$ & $\begin{array}{l}7(58 \%) \\
8(57 \%) \\
6(29 \%)\end{array}$ & $\begin{array}{l}25 \cdot 3 \pm 4 \cdot 2 \\
25 \cdot 5 \pm 5 \cdot 0 \\
13 \cdot 6 \pm 3 \cdot 1\end{array}$ \\
\hline
\end{tabular}




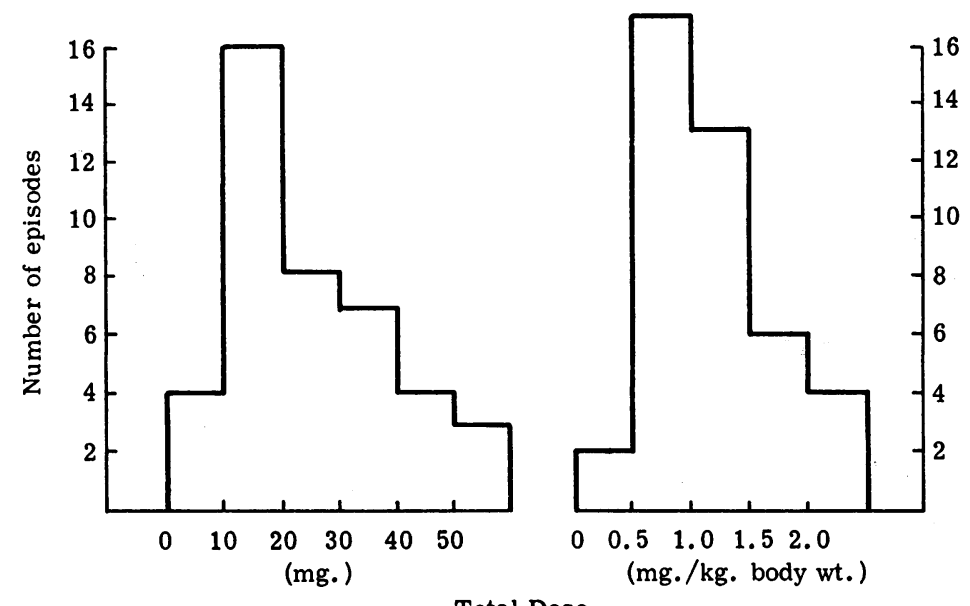

Total Dose

FIG. 3.-Total dose of intrathecal methotrexate administered (42 episodes of meningeal leukaemia).

which the incidence of meningeal involvement is related to over-all survival for the whole series of 98 patients who have died so far.

In Fig. 5, the time of diagnosis of each episode of meningeal leukaemia is shown in relation to each patient's whole course from diagnosis to death. It can be seen that meningeal involvement is usually a late complication, in the sense that it tends to develop towards the end of a

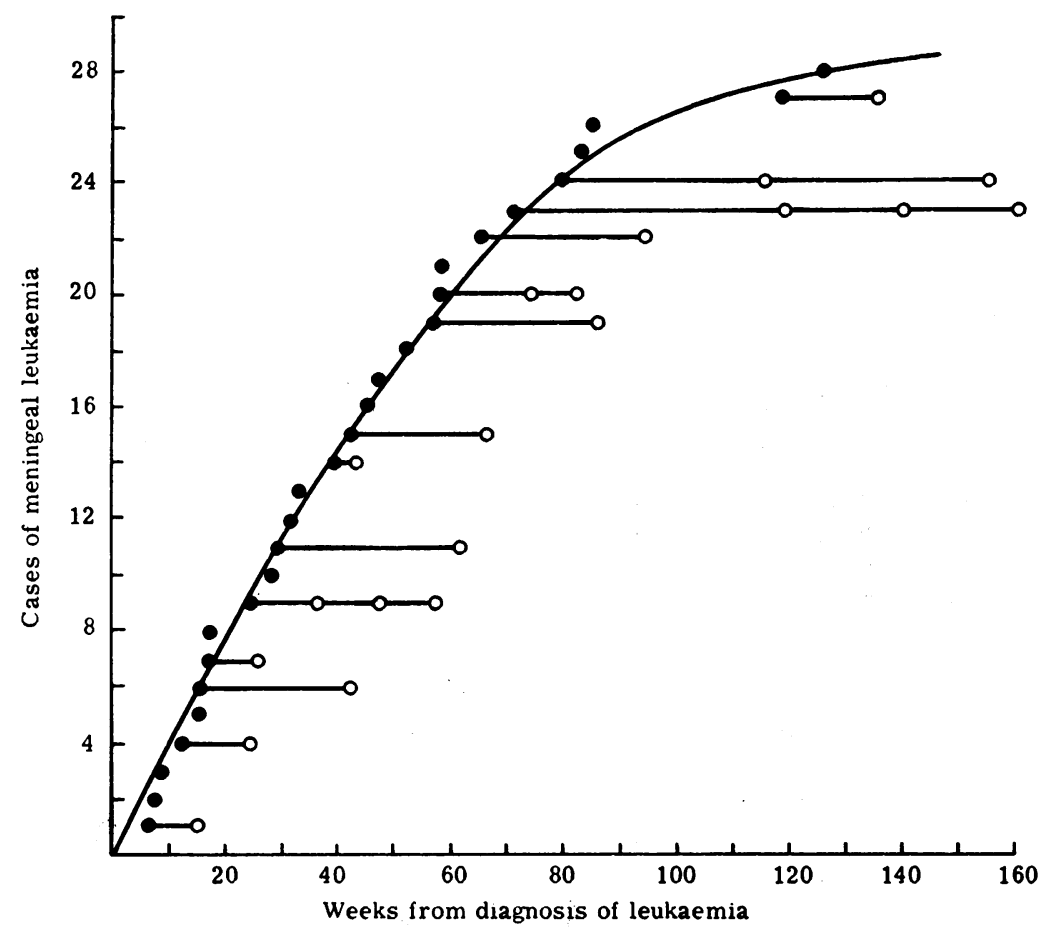

FIG. 4.-Time of diagnosis of meningeal leukaemia.

-, first episode; $\bigcirc$, subsequent episodes. 
patient's course ; those who develop meningeal leukaemia early, with few exceptions, are among the short survivors. Of the 27 patients who have died so far, $9(33 \%)$ were dead within 3 months of the first diagnosis of meningeal involvement and only 2 have survived for more than a year from that time; one of the living patients has so far survived 24 months since his first episode, and the other 5 months. The median survival for the whole series, from diagnosis of the first episode of meningeal involvement to death, is 24 weeks.

In order to determine whether the occurrence of meningeal involvement was of adverse prognostic significance for the course of the disease as a whole, each patient developing this complication at a given time after diagnosis was randomly paired with a control patient diagnosed in the same year (and therefore having the same therapy available), who had survived for the same period without developing meningeal involvement, and who did not subsequently do so. When the total survival from diagnosis to death of 26 such pairs was compared, it was found that 10 of the patients with meningeal involvement lived longer, and 16 of the controls. Such an uneven distribution would be expected to occur by chance once in 7 instances: though suggestive of an adverse effect of meningeal involvement, the difference does not reach conventional levels of statistical significance.

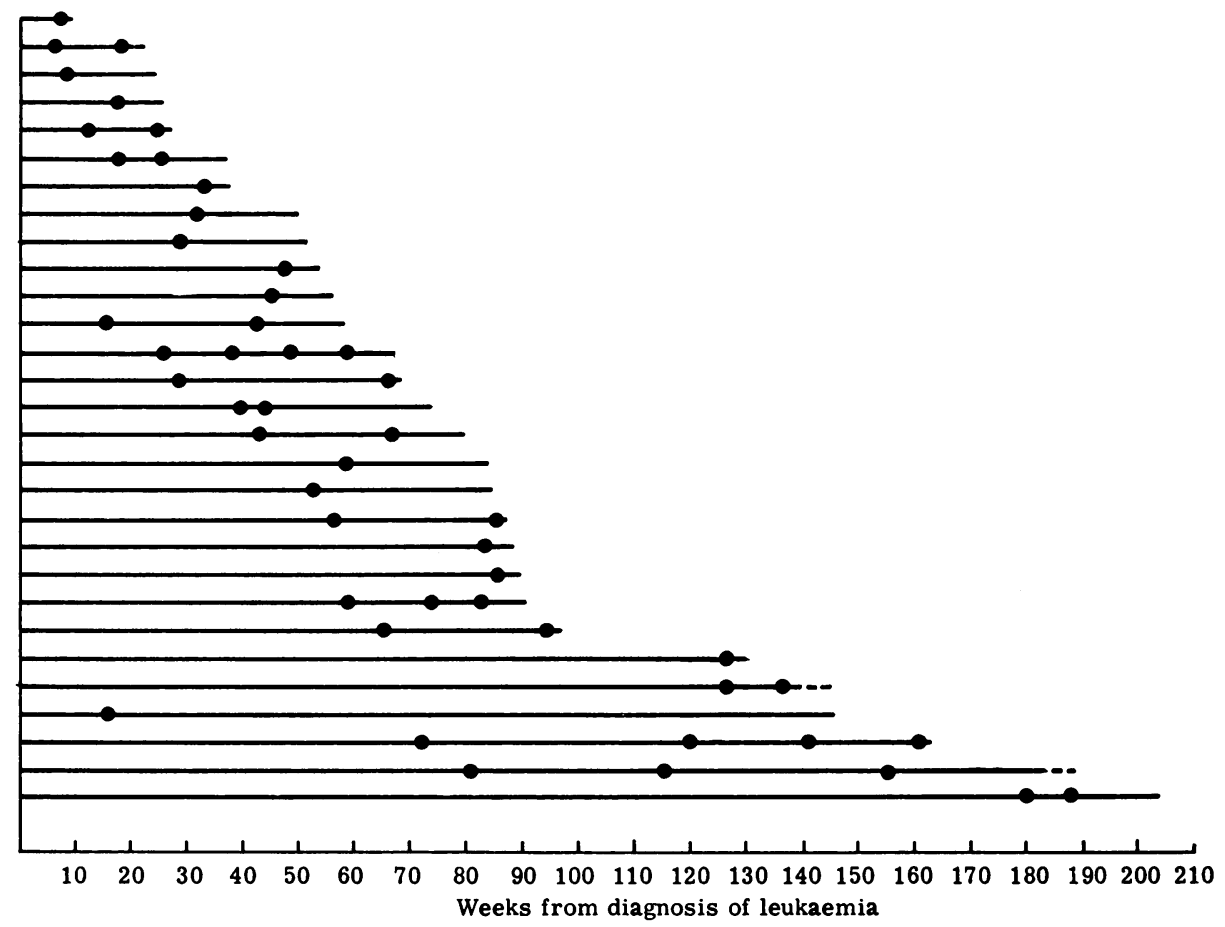

FIG. 5.-Relation of time of diagnosis of meningeal involvement to total duration of disease. Each horizontal line represents a patient's course from diagnosis to death.
TABLE VI

Incidence of Meningeal Involvement in Relation to Total Survival

\begin{tabular}{|c|c|c|c|c|c|}
\hline & \multicolumn{4}{|c|}{$\begin{array}{l}\text { Survival from Diagnosis of } \\
\text { Leukaemia to Death (mth.) }\end{array}$} & \multirow[t]{2}{*}{ Total } \\
\hline & $0-6$ & -12 & -18 & $>18$ & \\
\hline $\begin{array}{l}\text { All cases of leukaemia .. } \\
\text { Cases with meningeal } \\
\text { involvement ... }\end{array}$ & $\begin{array}{r}34 \\
3\end{array}$ & $\begin{array}{r}22 \\
6\end{array}$ & $\begin{array}{r}20 \\
6\end{array}$ & $\begin{array}{l}22 \\
12\end{array}$ & $\begin{array}{l}98 \\
27\end{array}$ \\
\hline $\begin{array}{l}\% \text { with meningeal } \\
\text { involvement .. }\end{array}$ & 9 & 27 & 30 & 55 & 28 \\
\hline
\end{tabular}

\section{Discussion}

The clinical features and CSF changes of meningeal leukaemia reported here are essentially similar to those which have previously been described (Sullivan, 1957; Shaw, Moore, Freireich, and Thomas, 1960; Pierce, 1962; Haghbin and Zuelzer, 1965; Hyman, Bogle, Brubaker, Williams, and Hammond, 1965a), except in the incidence of the hypothalamic syndrome, which was observed in an appreciably higher proportion of our patients than 
in previous series. Like other authors, we have also found that a high proportion of episodes of meningeal leukaemia occurred during haematological remission, maintained by antimetabolites. This tendency has usually been attributed to the failure of these drugs to cross the 'blood-brain barrier' in effective concentration, so that the leukaemic cells in the meninges are able to proliferate in a privileged environment. The occurrence of leukaemic infiltration of other organs-notably the gonadsduring bone-marrow remission, however, suggests that this may not be the whole explanation.

Meningeal infiltration is not a fatal complication of leukaemia, and practically always responds to treatment with intrathecal methotrexate, both symptomatically and in terms of a reduction of the CSF cell count to normal. The high recurrence rate, however, shows that this treatment is only palliative, and cannot be relied upon to eradicate the disease from the central nervous system. Rieselbach, Morse, Rall, Frei, and Freireich (1963) recorded relapses of meningeal leukaemia in 6 patients on maintenance intrathecal therapy with aminopterin, given at 3-4 week intervals, and Nies, Thomas, and Freireich (1965b) found that meningeal infiltration frequently persisted at necropsy, even in patients whose symptoms and cerebrospinal pleocytosis had been completely controlled throughout the course of their disease by means of such treatment. In view of these findings, it is doubtful whether regular maintenance therapy, involving monthly lumbar punctures, offers any advantage over the early clinical diagnosis of meningeal relapse, followed by re-treatment, as practised here. The mean and median duration of meningeal remissions in our series compare well with those of others treated with folic acid antagonists (Evans, D'Angio, and Mitus, 1964; Haghbin and Zuelzer, 1965; Hyman, Bogle, Brubaker, Williams, and Hammond, 1965b), and are distinctly better than the published results of radiotherapy which also has the disadvantage of its side-effects, particularly alopecia.

The association of a high initial CSF cell count with a tendency to early meningeal relapse has not been previously reported, but appears to be analogous to the frequently observed association between a high leucocyte count in the peripheral blood at the time of diagnosis of lymphoblastic leukaemia and the subsequent duration of total survival (Haut, Altman, Wintrobe, and Cartwright, 1959; Zuelzer, 1964). In the series of leukaemic patients from which this group with meningeal involvement was drawn, it had been observed that both the median duration of first remission and the median over-all survival were significantly longer for patients with less than 10,000 blasts per c.mm. peripheral blood at diagnosis than for those with more than this (R. M. Hardisty and M. Till, personal observations). A comparison of CSF and blood counts in these patients was therefore carried out, and revealed a significant association between the CSF cell count at diagnosis of each episode of meningeal leukaemia and the number of blasts in the patient's blood at the time of initial diagnosis of leukaemia (Table VII). Although such counts partly depend on the stage of disease at which the blood or CSF is first examined, they also probably reflect the rate of multiplication of the leukaemic cell population. These observations appear to support the concept that an individual patient's leukaemic cell line is characterized, throughout the course of the disease, by its own intrinsic growth characteristics which determine the rate at which the cells regenerate and hence the duration of remission following standard treatment.

TABLE VII

Correlation of Blast Cell Counts in Blood and Cerebrospinal Fluid

\begin{tabular}{c|c|c|c}
\hline $\begin{array}{c}\text { Blasts in Peripheral } \\
\text { Blood at Diagnosis } \\
\text { of Leukaemia } \\
\text { (per c.mm.) }\end{array}$ & $\begin{array}{c}\text { Blasts in CSF at Diagnosis of Meningeal } \\
\text { Involvement (per c.mm.) }\end{array}$ \\
\hline $0-10,000$ & $0-100$ & $101-1000$ & $>1000$ \\
\hline 10,000 & 9 & 7 & 6 \\
\hline
\end{tabular}

$\chi^{2}(2$ d.f. $)=8.4 ; 0.025>p>0.01$.

It is noteworthy that the initial blood count has no bearing on the time of development of meningeal involvement, nor is the CSF count related to the time till the next haematological relapse or till death: the proliferation of leukaemic cells in the bone-marrow and the meninges appears to proceed independently, presumably because they are exposed to different forms of treatment. It remains true that meningeal involvement, though responsive to treatment itself, normally indicates an advanced stage of the leukaemic process: hence its prognostic significance.

\section{Summary}

The clinical and laboratory findings are reported in 50 episodes of meningeal involvement occurring in 29 children with acute lymphoblastic leukaemia. The commonest presenting features were those of raised intracranial pressure, and rapid weight gain was frequently an early sign.

Treatment with intrathecal methotrexate was always clinically effective, but was followed by recurrence in more than half the cases. Early 
recurrence was particularly common in patients with high CSF cell counts; the possible significance of this observation is discussed.

Meningeal involvement was seen at all stages of the disease, but tended more often to occur towards the end of a patient's course. Its possible prognostic significance for the disease as a whole is examined.

This work was supported by a grant from the Leukaemia Research Fund, which we gratefully acknowledge. We should like to thank Dr. Richard Doll for statistical help.

\section{REFERENCES}

Evans, A. E., D'Angio, G. J., and Mitus, A. (1964). Central nervous system complications of children with acute leukemia. An evaluation of treatment methods. F. Pediat., 64, 94.

Haghbin, M., and Zuelzer, W. W. (1965). A long-term study of cerebrospinal leukemia. ibid., 67, 23.

Haut, A., Altman, S. J., Wintrobe, M. M., and Cartwright, G. E. (1959). The influence of chemotherapy on survival in acute leukemia. Comparison of cases treated during 1954 to 1957 with those treated during 1947 to 1954 . Blood, 14, 828 .

Hyman, C. B., Bogle, J. M., Brubaker, C. A., Williams, K., and Hammond, D. (1965a). Central nervous system involvement by leukemia in children. I. Relationship to systemic leukemia and description of clinical and laboratory manifestations. ibid., 25, 1 .

- - - and $-(1965 \mathrm{~b})$. Central nervous system involvement by leukemia in children. II. Therapy with intrathecal methotrexate. ibid., 25, 13.

Mathé, G., Schwarzenberg, L., Mery, A. M., Cattan, A., Schneider, M., Amiel, J. L., Schlumberger, J. R., Poisson, J., and Wajcner, G. (1966). Extensive histological and cytological survey of patients with acute leukaemia in 'complete remission'. Brit. med. f., 1, 640.

Nies, B. A., Bodey, G. P., Thomas, L. B., Brecher, G., and Freireich, E. J. (1965a). The persistence of extramedullary leukemic infiltrates during bone marrow remission of acute leukemia. Blood, 26, 133.

-, Thomas, L. B., and Freireich, E. J. (1965b). Meningeal leukemia. A follow-up study. Cancer (Philad.), 18, 546.

Pierce, M. I. (1962). Neurologic complications in acute leukemia in children. Pediat. Clin. N. Amer., 9, 425.

Rieselbach, R. E., Morse, E. E., Rall, D. P., Frei, E., III, and Freireich, E. J. (1963). Intrathecal aminopterin therapy of meningeal leukemia. Arch. intern. Med., 111, 620.

Shaw, R. K., Moore, E. W., Freireich, E. J., and Thomas, L. B. (1960). Meningeal leukemia: a syndrome resulting from increased intracranial pressure in patients with acute leukemia. Neurology (Minneap.), 10, 823.

Sullivan, M. P. (1957). Intracranial complications of leukemia in children. Pediatrics, 20, 757.

Zuelzer, W. W. (1964). Implications of long-term survival in acute stem cell leukemia of childhood treated with composite cyclic therapy. Blood, 24, 477. 